\title{
MENINGKATKAN KEMAMPUAN PEMAHAMAN KONSEP MATEMATIK SISWA DENGAN METODE PEMBELAJARAN THINKING ALOUD PAIR PROBLEM SOLVING (TAPPS)
}

\author{
Nur Widyasari ${ }^{1}$, Suyoto ${ }^{2}$, Nur Fauziyah ${ }^{3}$ \\ Mahasiswa PPG, Universitas Muhammadiyah Gresik ${ }^{1}$ \\ Program Studi PPG, Universitas Muhammadiyah Gresik ${ }^{2,3}$ \\ Email:nurwdsr1@gmail.com
}

\begin{abstract}
Abstrak
Tujuan penelitian ini mengkaji 1) Peningkatan kemampuan pemahaman matematika siswa setelah menggunakan metode pembelajaran TAPPS.2) Aktivitas Siswa dalam Pembelajaran dengan metode TAPPS. 3)Respon siswa terhadap pembelajaran matematika dengan menggunakan metode pembelajaran TAPPS. Penelitian ini dilaksanakan di MTs Asy-Syariah tahun ajaran 2012/2013 pada bulan September-Oktober 2013.Metode yang digunakan dalam penelitian ini adalah Penelitian Tindakan Kelas (PTK) yang terdiri dari dua siklus. Instrumen penelitian yang digunakan adalah tes pemahaman konsep, wawancara, lembar observasi, dan jurnal harian siswa.Hasil penelitian mengungkapkan bahwa penerapan Model Pembelajaran Thinking Aloud Pair Problem Solving (TAPPS) dapat meningkatkan kemampuan pemahaman matematika siswa. Hal ini terlihat dari peningkatan rata-rata skor pemahaman konsep siswa dari 68,13 menjadi 78,06 pada siklus II. Kemudian terlihat dari kenaikan persentase indikator pemahaman konsep matematika siswa mencapai lebih dari $70 \%$ atau dalam kategori baik. Indikator pemahaman konsep antara lain Instrumental dan Relasional. Aktivitas siswa selama proses pembelajaran matematika dengan metode TAPPS sangat baik. Hal tersebut dapat dilihat berdasarkan Rata-rata aktivitas siswa pada siklus I sebesar 63,33\% meningkat menjadi $87,78 \%$ pada siklus II. Selain itu, hasil penelitian juga menunjukan bahwa pada umumnya siswa memberikan respon positif terhadap pembelajaran matematika TAPPS. Hal ini dapat dilihat melalui hasil jurnal harian yang menunjukan persentase respon positif siswa meningkat dari $60,16 \%$ pada siklus I menjadi $81,82 \%$ pada siklus II.
\end{abstract}

Kata kunci: Thinking Aloud Pair Problem Solving (TAPPS), pemahaman konsep

\begin{abstract}
Abstrack
The purpose of this study examines 1) Improving students' mathematical understanding ability after using the TAPPS learning method.2) Student Activities in Learning with the TAPPS method. 3) Student responses to mathematics learning by using the TAPPS learning method. This research was conducted at MTs Asy-Syariah 2012/2013 school year in September-October 2013. The method used in this study is Classroom Action Research (CAR) which consists of two cycles. The research instrument used was a concept understanding test, interviews, observation sheets, and a student's daily journal. The results revealed that the application of the Thinking Aloud Pair Problem Solving Learning Model (TAPPS) could improve students' mathematical understanding abilities. This can be seen from the increase in the average score of students' concept understanding from 68.13 to 78.06 in the second cycle. Then it can be seen from the increase in the percentage of indicators of understanding students' mathematical concepts reaching more than $70 \%$ or in either category. Indicators of understanding concepts include Instrumental and Relational. Student activities during the mathematics learning process using the TAPPS method are very good. This can be seen based on the average activity of students in the first cycle of $63.33 \%$ increased to $87.78 \%$ in the second cycle. In addition, the results of the study also showed that
\end{abstract}


students generally responded positively to the learning of TAPPS mathematics. This can be seen through the results of daily journals that show the percentage of positive student responses increased from $60.16 \%$ in the first cycle to $81.82 \%$ in the second cycle. From the results of data analysis, it can be concluded that the mathematical reasoning ability of students in class XII IPA 2 has met the indicators of research success after the second cycle, as many as 67\% (24 students) meet the criteria of good reasoning. The implementation of learning is classified as good in the second cycle, namely all learning is carried out with a percentage of $88.5 \%$.

Keywords: Thinking Aloud Pair Problem Solving (TAPPS), concept understanding.

\section{PENDAHULUAN}

Pendidikan pada dasarnya merupakan proses untuk membantu manusia dalam mengembangkan potensi dirinya sehingga mampu menghadapi setiap perubahan yang terjadi. Selain itu fungsi lain dari pendidikan adalah mengurangi kebodohan, keterbelakangan dan kemiskinan karena ilmu pengetahuan dan keterampilan yang diperoleh dapat menjadikan seseorang mampu mengatasi problematika. Salah satu pelajaran yang sering ditemui di dunia pendidikan adalah pelajaran matematika.

$$
\text { Pelajaran matematika }
$$

merupakan ilmu dasar dari segala ilmu pengetahuan. Selain itu juga menjadi dasar dari pengembangannya dan berperan penting dalam perkembangan ilmu pengetahuan suatu negara. Dasar dari mempelajari matematika yaitu dengan memahami konsep. Hal ini sangat penting dan perlu ditanamkan sejak dini. Karena konsep matematika yang satu dengan yang lain berkaitan serta untuk mempelajarinya harus runtut dan berkesinambungan. Jika siswa telah memahami konsep-konsep dasar matematika, maka akan memudahkan siswa dalam mempelajari konsep-konsep matematika berikutnya yang lebih kompleks. Suhendra (2007) mengatakan bahwa seseorang dikatakan memahami konsep matematika bila ia telah mampu melakukan beberapa hal, antara lain: a) Menemukan (kembali) suatu konsep yang sebelumnya belum diketahui berlandaskan pada pengetahuan dan pengalaman yang telah diketahui dan dipahaminya sebelumnya;

Mendefinisikan atau mengungkapkan suatu konsep dengan cara membuat kalimat sendiri namun tetap memenuhi ketentuan berkenaan dengan gagasan konsep tersebut; c) Mengidentifikasi hal-hal yang relevan dengan suatu konsep dengan cara-cara yang tepat; d) Memberikan contoh (dan bukan 
contoh) atau ilustrasi yang berkaitan dengan suatu konsep guna memperjelas konsep tersebut.

Namun dalam kenyataannya dapat dilihat dari survei internasional TIMSS dan PISA, kemampuan matematika siswa di Indonesia masih redah. Salah satu faktor utamanya adalah kurangnya kemampuan pemahaman terhadap konsep-konsep yang diajarkan. Hal tersebut disebabkan pembelajaran konsep dan prosedur dalam matematika kurang dipraktekkan di sekolah-sekolah selama ini. Siswa hanya menghafalkan saja semua rumus atau konsep tanpa memahami maknanya, sehingga mereka tidak mampu menerapkannya. Selain itu proses pembelajaran di sekolah biasanya siswa harus menerima pelajaran dari guru dan mereka dipaksakan untuk dapat mengerjakan soal yang diberikan oleh guru tanpa mempertimbangkan keadaan kemampuan matematika siswa tersebut. Akibatnya siswa menganggap pembelajaran matematika kurang menarik dan membosankan. Hal ini secara tidak langsung berdampak terhadap kemampuan pemahaman konsep matematika siswa tersebut yang kurang. Maka dari itu perlu dilakukan peningkatan pembelajaran dengan menggunakan berbagai pendekatan dan metode pembelajaran yang dapat meningkatkan pemahaman, kemampuan pemecahan masalah dan kemampuan berpikir siswa. Salah satu metode yang dapat digunakan dalam pembelajaran matematika adalah metode pembelajaran Thinking Aloud Pair Problem Solving (TAPPS).

Thinking Aloud Pair Problem Solving (TAPPS) adalah sebuah metode artikulasi-refleksi yang dikembangkan dan diteliti selama bertahun-tahun oleh Whimbey dan Lochhead pada tahun 1999. Thinking Aloud artinya berpikir lisan, Pair artinya berpasangan dan Problem Solving artinya penyelesaian masalah. Jadi Thinking Aloud Pair Problem Solving (TAPPS) dapat diartikan sebagai teknik berfikir lisan secara berpasangan dalam penyelesaian masalah yang merupakan salah satu metode pembelajaran yang dapat menciptakan kondisi belajar aktif kepada siswa. Jenis pembelajaran ini membuat siswa untuk mencari tahu sumber-sumber pengetahuan yang relevan. Sehingga metode TAPPS memberikan tantangan kepada siswa untuk belajar memahami dan berfikir sendiri .

Metode TAPPS ini merupakan salah satu metode pembelajaran yang menekankan pada keaktifan siswa 
dalam menggunakan semua indera dan kemampuan berpikir untuk memahami konsep yang dipelajari. Pada metode ini siswa di kelas dibagi menjadi beberapa kelompok. Setiap kelompok terdiri dari dua pihak. Satu pihak sebagai Problem Solver (PS) dan satu pihak sebagai Listener (L). Setiap anggota tim memiliki tugas masingmasing yang akan mengikuti aturan tertentu. Dengan adanya kegiatan ini, siswa dituntut untuk bersikap aktif dan mengeluarkan sebanyak-banyaknya informasi yang mereka ketahui dan pada akhirnya mereka mengkonstruksi pengetahuan yang mereka dapatkan. Pembentukan pengetahuan siswa akan menghasilkan suatu pemahaman dalam diri siswa tersebut. Sehingga konsep yang diperoleh dapat tertanam lebih kuat dan prestasi belajar yang dicapai oleh siswa menjadi lebih baik.

Hal ini sejalan dengan pendapat Slavin yang mengatakan bahwa : "TAPSS permits rehearse the concepts, relate them to existing frameworks, and produce a deeper understanding of material”. Maksudnya dengan menggunakan metode TAPSS siswa dapat memikirkan pemecahan dari suatu masalah, kemudian mengungkapkan gagasan dan pemikirannya dalam menemukan solusi sehingga membantu siswa dalam menyelesaikan suatu permasalahan yang berhubungan dengan konsepkonsep matematika. Peningkatan kemampuan pemahaman konsep dalam pembelajaran matematika di sekolah sangatlah penting, karena hal ini sesuai dengan tujuan pembelajaran matematika. Dengan dimilikinya kemampuan pemahaman konsep diharapkan berdampak pada pengembangan daya pikir terhadap kemampuannya dalam meyelesaikan masalah matematika sehingga kemampuan hasil belajar matematika siswa meningkat. Oleh karena itu, Metode TAPPS ini dapat menjadi salah satu alternatif untuk meningkatkan kemampuan pemahaman konsep matematika matematika siswa.

Berdasarkan uraian tersebut maka penulis mencoba mengadakan suatu penelitian yang berjudul "Meningkatan Kemampuan Pemahaman Konsep Matematika Siswa dengan Metode Pembelajaran Thinking Aloud Pair Problem Solving (TAPPS)".

\section{METODE}

Jenis penelitian ini adalah Penelitian Tindakan Kelas atau disingkat dengan PTK. Menurut Arikunto, dkk (2012:16) bahwa 
penelitian tindakan kelas terdiri dari beberapa tahap, antara lain: 1) dan berulang sampai dengan penelitian perencanaan, 2) tindakan, 3 dikatakan behasil, sehingga pengamatan, dan 4) refleksi. Tahapan membentuk siklus yang dapat dilihat dalam PTK dilakukan secara bertahap pada gambar berikut.

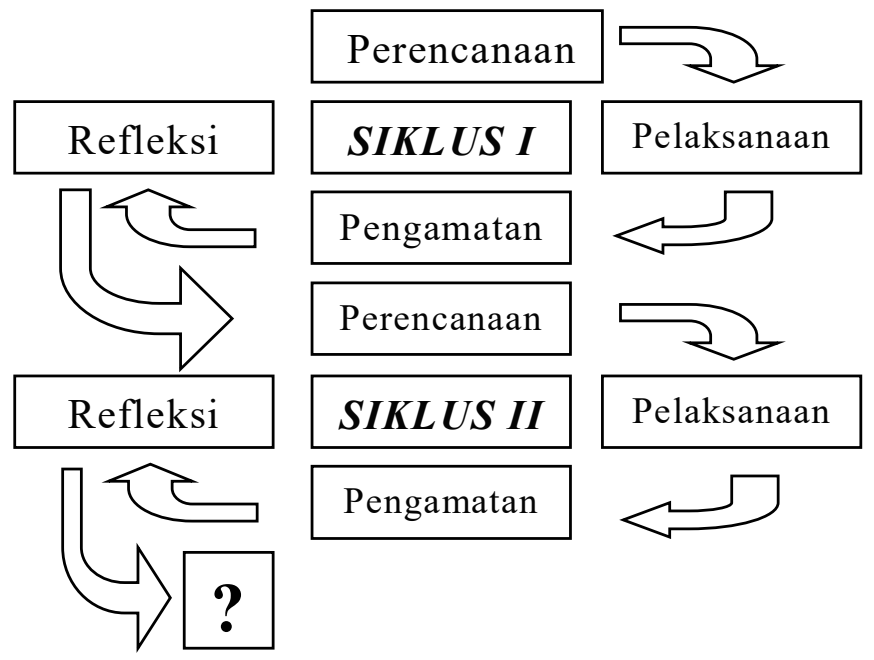

Sumber: Arikunto, dkk (2012:16)

Gambar 1. Siklus PTK

Siklus 1. Refleksi dilaksanakan pada setiap akhir pelaksanaan pembelajaran. Pada tahap ini observer menjelaskan hasil pengamatannya selama proses pembelajaran berlangsung kemudian peneliti melakukan konfirmasi dan mengecek kesesuaian datanya. Data tersebut kemudian dianalisis dengan menggunakan teknik analisis data, dan hasil analisis data tersebut digunakan untuk mengkaji kelemahan serta keunggulan tindakan pada siklus I. Pada akhir siklus hasil refleksi digunakan untuk melakukan perbaikan perencanaan jika penelitian masih dilanjutkan.
Siklus II. Jika pada siklus I, masalah yang dirumuskan sudah terjawab maka penelitian dapat dihentikan. Jika pada siklus I, masalah yang dirumuskan belum terjawab maka penelitian akan dilanjutkan pada siklus II. Perencanaan siklus II disesuaikan dengan hasil refleksi pada siklus I, sehingga keberhasilan pada siklus I dapat diperbaiki pada siklus II. Hal tersebut akan dilanjutkan pada siklus selanjutnya sampai masalah yang dirumuskan terjawab.

Subjek penelitian ini adalah peserta didik kelas XI AKN (akuntansi) SMK Madinatul Ulum Baureno, yang terdiri dari 15 siswa 
Perempuan dan 5 siswa laki-laki. Subjek penelitian ini ditentukan dengan berdasarkan hasil observasi dilakukan oleh guru pengajar matematika di SMK Madinatul Ulum Bauereno. Metode yang akan digunakan dalam penelitian ini adalah tes, observasi, wawancara, dan jurnal harian. Sehingga instrumen yang diperlukan pada penelitian ini adalah instrumen untuk tes pemahaman konsep dan lembar pengamatan penerapan TAAPS. Pada kemampuan penalaran matematika pada penelitian ini dikatakan berhasil jika:

$$
\geq 65 \% \text { dari SDB : kemampuan }
$$

penalaran baik

$$
<65 \% \text { dari SDB : kemampuan }
$$

penalaran tidak baik

Keterangan: $\mathrm{SDB}=$ Jumlah keseluruhan siswa yang termasuk dalam kriteria sangat baik atau baik dalam bernalar

Sedangkan untuk mengetahui kriteria dari keterlaksanaan pembelajaran tersebut berikut konveksi nilainya yang disajikan dalam Tabel 1 :

Tabel 1. Konversi Nilai Keterlaksanaan Pembelajaran

\begin{tabular}{|l|l|}
\hline Rata-rata nilai & Kriteria \\
\hline $1,00 \leq \mathrm{RNK}<1,75$ & Tidak baik \\
$1,75 \leq \mathrm{RNK}<2,50$ & Kurang baik \\
$2,50 \leq \mathrm{RNK}<3,25$ & Baik \\
$3,25 \leq \mathrm{RNK}<4,00$ & Sangat baik \\
\hline
\end{tabular}

(Lince dalam Suryakartika, 2009:56)

Keterangan: $\mathrm{RNK}=$ Rata-rata Nilai Kategori

Hasil penelitian yang

diharapkan dalam penelitian ini adalah meningkatnya kemampuan pemahaman konsep matematik siswa melalui metode pembelajaran TAPPS. Penelitian ini akan dihentikan jika:

1. Hasil tes kemampuan pemahaman konsep yang diberikan pada setiap akhir siklus menunjukkan bahwa nilai rata-rata siswa mencapai $\geq 70$. Nilai 70 ini sesuai dengan KKM yang ditetapkan pada materi relasi dan fungsi.

2. Hasil Persentase skor tiap indikator kemampuan pemahaman konsep yaitu instrumental dan relasional mencapai $70 \%$ atau termasuk dalam kategori baik. 
Jika kedua indikator kinerja tersebut telah terpenuhi maka penelitian tindakan ini berhasil dan tindakan penelitian dihentikan. Sebaliknya, jika salah satu atau kedua indikator keberhasilan kinerja belum terpenuhi, maka tindakan penelitian ini harus dilanjutkan ke siklus berikutnya, dan disertai dengan adanya perbaikanperbaikan yang menjadi kekurangan dari siklus sebelumnya.

\section{HASIL DAN PEMBAHASAN}

Penerapan pembelajaran dengan metode Thinking Aloud Pair Problem Solving (TAPPS) dalam pembelajaran matematika utamanya dilaksanakan peneliti dengan memberikan kesempatan kepada siswa untuk menggali pengetahuan sendiri, menjelaskan, dan menanggapi penjelasan temannya yang berimplikasi kepada meningkatnya kemampuan pemahaman konsep matematik siswa melalui peran mereka sebagai problem solver dan listener. Peran siswa sebagai problem solver dan listener mengarahkan aktivitas belajar siswa dalam melatih kemampuan berpikir dan verbalisasi pemahaman siswa.

Pada siklus I dari hasil pengamatan menunjukkan siswa terlihat cukup kesulitan untuk beradaptasi dengan aktivitas belajar dengan metode TAPPS yang sebelumnya tidak terbiasa mereka lakukan. Hal itu nampak sangat terlihat pada penjelasan pengerjaan soal, yang kurang mendapat perhatian di awal siklus. Tidak jauh berbeda dengan aktivitas listener merupakan aktivitas yang belum biasa mereka lakukan sebelumnya dalam menanggapi permasalahan yang sedang dijelaskan oleh temannya hal ini mendapat perhatian lebih untuk meningkatkan aktivitas belajar pada siklus II.

Pada siklus II dari hasil penghamatan siswa terlihat cukup antusias dalam pembelajaran. Peningkatan aktivitas dalam pembelajaran matematik, menunjukkan aktivitas belajar siswa dalam pembelajaran TAPPS pada siklus II lebih baik dari siklus I. Pada siklus I aktivitas belajar siswa mencapai ratarata persentase $63,33 \%$, namun pada siklus II meningkat menjadi $87,78 \%$. Hal ini menunjukkan bahwa penerapan metode TAPPS meningkatkan aktivitas belajar siswa sebesar 24,45\%.

Pada siklus I diketahui bahwa rata-rata nilai tes pemahaman konsep matematika siswa pada siklus I adalah 67,42 dengan tingkat ketuntasan $56,25 \%$ dari jumlah siswa 32 , dan menunjukan bahwa $43,75 \%$ siswa memperoleh nilai $<70$. Modus dari 
nilai siswa adalah 72,5 artinya bahwa banyak siswa yang memperoleh nilai tersebut dengan median 68,75. jangkauan nilai siswa adalah 40 dan rentang nilai siswa sebesar 40 dengan nilai tertinggi 85 dan nilai terendah 45 hal ini menunjukan bahwa perbedaan nilai siswa yang berkemampuan tinggi cukup jauh dengan siswa yang berkemampuan rendah. Kemampuan pemahaman konsep siswa pada siklus II di peroleh hrata-rata nilai tes pemahaman konsep matematika siswasebesar 76,56 dengan tingkat ketuntasan $84,38 \%$ dari jumlah siswa 32, dan menunjukan bahwa 15,63\% siswa memperoleh nilai $<70$. Modus dari nilai siswa adalah 75 artinya bahwa banyak siswa yang memperoleh nilai tersebut dengan median 75 jangkauan dan rentang nilai siswa sebesar 35 dengan nilai tertinggi 95 dan nilai terendah 60 .

Hasil tes pemahaman konsep matematika siswa mengalami peningkatan rata-rata dari siklus I sebesar 68,13 menjadi 78,06 pada siklus II. Hal ini menunjukkan bahwa pembelajaran matematika melalui TAPPS dapat meningkatkan kemampuan pemahaman konsep matematik siswa. Kegiatan belajar juga menjadi lebih kondusif karena siswa dibiasakan untuk menggunakan kemampuan pemahaman konsepnya dalam penyelesaian masalah yang diberikan. Peningkatan yang diperoleh siswa dari nilai tes akhir siklus I menunjukan Nilai Rata-rata mencapai 61,47. Sedangkan rata-rata nilai siswa pada siklus II mencapai 74,53 . Hal ini menunjukan terjadinya peningkatan kemampuan pemahaman konsep matematika siswa. Pembelajaran dengan menggunakan model Thinking Aloud Pair Problem Solving (TAPPS) membuat siswa dapat memahami dan menjelaskan konsep/ide-ide matematis dengan mengalaminya sendiri dengan penjelasan soal sebagai problem solver dan menerima atau mendengarkan penjelasan sebagai listener dari temannya sendiri.

Respon siswa terhadap pembelajaran diperoleh dari Hasil wasancara dan Jurnal harian yang dilakukan terhadap subjek penelitian. Pada jurnal harian rata-rata persentase respon positif siswa terhadap metode TAPPS meningkat yaitu dari 60,16\% pada siklus I menjadi $81,25 \%$ pada siklus II. Sedangkan rata-rata persentase respon negatif siswa menurun dari $28,13 \%$ pada siklus I menjadi $15,63 \%$ pada siklus II, begitu pula siswa rata-rata persentase respon netral siswa menurun dari $11,72 \%$ pada siklus I menjadi 3,13\% pada siklus II. 
Dari hasil wawancara terhadap beberapa siswa diperoleh informasi bahwa penerapan pembelajaran dengan metode TAPPS memberikan nuansa belajar yang baru bagi siswa. Belajar matematika dengan cara yang berbeda membuat siswa bersemangat dalam belajar matematika. Masing-masing siswa juga merasakan manfaat penerapan metode TAPPS dalam pembelajaran matematika, di antaranya siswa yang kemampuan matematikanya rendah dapat menambah ilmu dan pengetahuan mereka dalam menyelesaikan masalah/soal melalui teman/pasangannya dalam diskusi metode TAPPS. Sementara itu siswa yang memiliki kemampuan lebih baik akan semakin mereasa bangga dengan mempresentasikan kemampuan yang dimilikinya kepada teman pasangannya.

Beberapa siswa juga mengungkapkan bahwa belajar lebih menyenangkan apabila dapat bertukar pikiran/berdiskusi dengan teman. Sehingga dapat dikatakan metode TAPPS memberikan pengaruh positif terhadap pola belajar siswa. Beberapa aktivitas yang dianggap kurang seperti memperhatikan penjelasan guru atau teman, mengajukan pertanyaan maupun pendapat, kesiapan siswa dalam belajar di sekolah serta aktivitas-aktivitas lain yang sebelumnya tidak pernah dilakukan siswa telah menunjukkan peningkatan setelah diterapkan pembelajaran dengan metode TAPPS. Selain itu aktivitas siswa yang kurang terarah seperti mengobrol, bercanda, melamun dan lain-lain menjadi lebih berkurang atau terminimalisir.

\section{PENUTUP}

\section{Simpulan}

Berdasarkan hasil analisis dan pembahasan pembelajaran dengan model TAPPS dapat meningkatkan kemampuan pemahaman konsep matematika siswa. Hal ini terlihat dari: 1. Penerapan model pembelajaran Thingking Aloud Pair Problem Solving (TAPPS) dapat meningkatkan kemampuan pemahaman matematika siswa. Peningkatan dapat terlihat dari rata-rata hasil tes kemampuan pemahaman konsep dari siklus I ke siklus II. Kemampuan pemahaman konsep yang meningkat dengan model pembelajaran TAPPS meliputi instrumental dan relasional. Kemampuan instrumental pada siswa meningkat melalui model pembelajaran TAPPS. Hal ini terlihat dari kenaikan persentase indikator kemampuan 
pemahaman instrumental siswa dari kategori cukup pada siklus I menjadi baik pada siklus II. Peningkatan kemampuan pemahaman relasional pada siswa diketahui pada saat siswa mampu mengaitkan konsep tepat dalam menyelesaikan soal. Hal ini didukung oleh peningkatan kategori cukup pada siklus I menjadi baik pada siklus II.

2. Penggunaan metode TAPPS dalam proses pembelajaran matematika dapat meningkatkan aktivitas siswa. Rata-rata aktivitas siswa pada siklus I sebesar $63,33 \%$ meningkat $87,78 \%$ pada siklus II. Hal tersebut dapat dilihat berdasarkan lembar observasi siswa selama proses pembelajaran Dan telah mencapai indikator keberhasilan penelitian yaitu aktivitas siswa mencapai $\quad>70 \%$. Aspek aktivitas yang diamati meliputi Siswa siap menerima pelajaran dan memperhatikan penjelasan dari guru, Menggali pengetahuan awal melalui lembar kerja siswa (LKS), Antusias mengerjakan tugas individu, Siswa menuliskan dan menjelaskan identifikasi masalah mengenai yang diketahui dan yang ditanyakan di dalam soal, Siswa menuliskan dan menjelaskan konsep, cara atau rumus yang digunakan untuk menyelesaikan masalah, Siswa menuliskan dan menjelaskan cara perhitungan dalam menyelesaikan soal, Siswa menuliskan dan menjelaskan kembali jawaban hasil pemeriksaan terkait penyelesaian masalah/soal, Siswa menggambarkan ilustrasi masalah pada lembar kerja siswa $\quad$ (LKS), $\quad$ Siswa Mendengarkan dan memberi tanggapan kepada temanya. Pada setiap aspek yang diamati aktivitas siswa terlihat meningkat.

3. Respon siswa terhadap pembelajaran matematika menggunakan model pembelajaran TAPPS sangatlah positif. Hal ini terlihat dari ratarata hasil respon positif siswa pada jurnal harian siswa yang meningkat dari siklus I ke siklus II. Selain itu terlihat juga dari aktivitas siswa yang meningkat berdasarkan pengamatan hasil observasi. Aktivitas siswa pada 
siklus I termasuk dalam kategori cukup, pada siklus II termasuk dalam kategori sangat baik. Sehingga respon siswa selama pembelajaran terlihat positif.

\section{Saran}

Berdasarkan hasil penelitian yang telah diperoleh, peneliti dapat memberikan saran-saran sebagai berikut:

1. Bagi sekolah dan pihak guru pada khususnya, hendaknya menggunakan model pembelajaran TAPPS sebagai alternatif dalam proses pembelajaran terutama dalam meningkatkan kemampuan pemahaman konsep.

2. Pada penelitian ini, kemampuan pemahaman konsep yang diteliti hanya dibatasi pada indikator pemahaman konsep skemp. Bagi peneliti selanjutnya, hendaknya dapat mengembangkan indikator pemahaman konsep lainnya.

3. Pada penelitian ini, model pembelajaran TAPPS diteliti untuk meningkatkan kemampuan pemahaman konsep. Bagi peneliti selanjutnya, hendaknya dapat meneliti apakah model pembelajaran TAPPS dapat meningkatkan kemampuan matematika lainnya, tidak terbatas hanya pada kempuan pemahaman matematika siswa.

\section{DAFTAR PUSTAKA}

Arikunto, Suharsimi. Penelitian Tindakan Kelas. Jakarta: Bumi Aksara. 2007.

Suhendra, dkk. 2007. Pengembangan Kurikulum dan Pembelajaran Matematika. Jakarta: Universitas Terbuka Slavin. 2012. Thinking Aloudd Pair Problem Solving (TAPPS). (http://www.wcer.wisc.edu/ $\operatorname{archive} / \mathrm{cl1} / \mathrm{cl} /$ doingcl/tapps. htm 